\title{
ANALISIS PERBANDINGAN REGULASI DI SEKTOR PERTANIAN SEBELUM DAN SESUDAH IMPLEMENTASI PSAK 69 AGRIKULTUR
}

\author{
Samuel Simanjuntak ${ }^{1}$, Lindrianasari Lindrianasari ${ }^{* 2}$, Ninuk D. Kesumaningrum ${ }^{3}$, Reni \\ Oktavia $^{4}$ \\ ${ }^{1243}$ Jurusan Akuntansi, Fakultas Ekonomi, Universitas Lampung, Lampung \\ *Email: lindrianasari@feb.unila.ac.id
}

\begin{tabular}{l}
\hline Keywords: \\
\hline Earning response \\
coefficient, agriculture, \\
implementation PSAK \\
69 and regulation \\
\hline
\end{tabular}

\section{Article Information:}

Received:

2020-05-30

Accepted:

2020-07-09

Available online:

2020-07-18

\begin{abstract}
Implementation of PSAK 69 Agriculture was second year implemented, since 1 January 2018. Mostly, every new regulation have a pro and contra for assumed this regulation. PSAK 69 is the hope of agriculture business actors regarding the clarity of regulations that accommodate agricultural business activities. Because before PSAK 69 was inforced, there is no regulation can accommodate the agriculture business on specific. So, this study wants to explain how implementation PSAK 69 for annual report in many agriculture companies, and give an explaination what's the difference of the regulation before implementation PSAK 69 and after implementation PSAK 69.
\end{abstract}

\section{PENDAHULUAN}

Sektor pertanian secara historis berfungsi sebagai pilar ekonomi Indonesia, menyediakan pekerjaan untuk sekitar $25.01 \%$ dari populasi tenaga kerja dan berkontribusi 13\% dari PDB negara dengan menyediakan lapangan kerja bagi 35,7 juta orang (Badan Pusat Statistik, 2018). Sektor pertanian secara strategis dipandang oleh pemerintah sebagai hal yang penting.

Setiap tahun tingkat produk domestik Indonesia meningkat, namun hal ini tidak sejalan dengan nilai pasar produk agrikultur Indonesia. Nilai gross value added sektor agrikultur terhadap GDP Indonesia mengalami penurunan dalam 2 (dua) tahun terakhir. Disisi lain, pertumbuhan nilai produk agrikultur terus meningkat dalam kurun waktu 5 tahun terakhir. Eksistensi sektor agrikultur dalam perekonomian Indonesia tidak dapat dikesampingkan dengan tingkat gross value added 12,8\% pada tahun 2018 terhadap gross domestic product dan tingkat pertumbuhan products market value $16,5 \%$. 



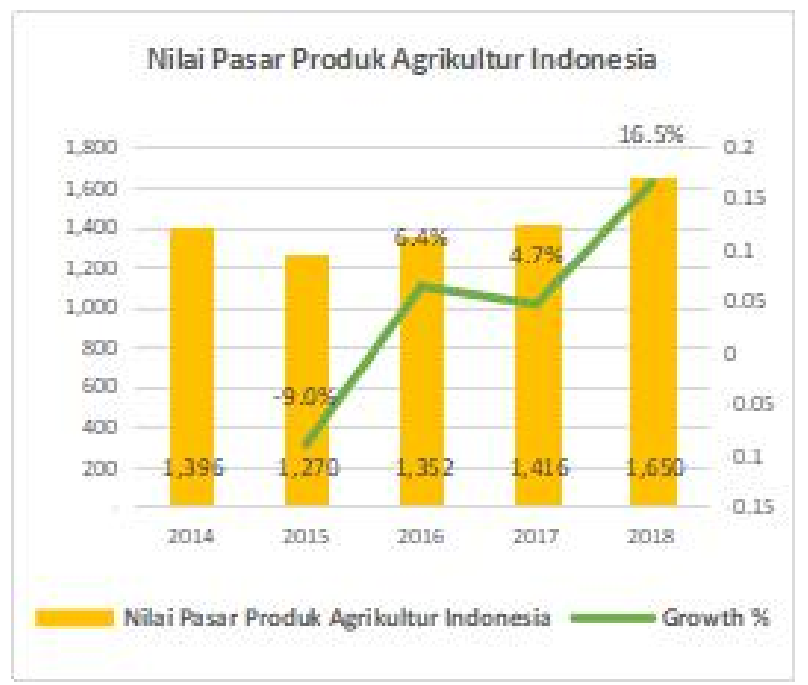

\section{Gambar 1}

Nilai Pasar Produk Agrikultur Indonesia

Sumber: Badan Pusat Statistik, 2018

Ketidakseiramaan antara nilai produk agrikultur dengan kontribusi sektor agrikultur terhadap peningkatan PDB Indonesia ini dipengaruhi banyak hal. Salah satu yang paling signifikan adalah sebuah peraturan atau kebijakan dalam hal ini yakni standar akuntansi yang berlaku. Penerapan PSAK 69 agrikultur merupakan bentuk usaha untuk mengembangkan dan memajukan sektor agrikultur. Implementasi PSAK 69 berusaha mengakomodir pelaporan keuangan perusahaan dan mampu mendorong minat investor atas laporan keuangan yang baik.

Sebuah pemahaman dan pengertian akan sebuah regulasi atau peraturan yang tepat dan baik memiliki dampak terhadap output yang dihasilkan, apakah itu output yang positif ataupun output yang negatif. Tergantung pada pemahamannya ketika mendapatkan informasi yang jelas. Umumnya peraturan atau ketentuan dibuat memiliki tujuan yang berkelanjutan, sehingga tidak hanya menfokuskan pada hal yang minor, melainkan terhadap yang lebih luas. Dalam dunia usaha sebuah kebijakan atau ketentuan memiliki andil yang cukup besar terhadap respon para pemangku kepentingan, contohnya dalam hal ini adalah PSAK 69 agrikultur. PSAK 69 agrikultur merupakan terobosan dan solusi dalam penyelasaian terkait praktik akuntansi agrikultur dan aset biologis yang masih bias (Martani, 2018). Pemahaman yang baik terhadap PSAK 69 agrikultur memungkinkan untuk tersampaikannya informasi keuangan yang jelas dan teliti pada perusahaan sektor agrikultur.

\section{METODE PENELITIAN}

Penelitian ini pada dasarnya dimaksudkan untuk memahami bagaimana perbandingan penerapan sebelum dan setelah penerapan PSAK 69 agrikultur pada perusahaan sektor 
agrikultur. Metode analisa data yang digunakan adalah analisis kualitatif komparatif. Analisis kualitatif komparatif yaitu analisis yang dilakukan dengan membandingkan antara suatu variabel yang berpasangan dengan perbedaan faktor yang mempengaruhi suatu variabel, baik perbedaan waktu, tempat, dan sebagainya yang bisa memberikan dampak perbedaan (Thiem dan Dusa, 2019).

Penelitian ini memaparkan perihal perbedaan atau perbandingan dalam penyusunan laporan keuangan khususnya masalah pengukuran, pengakuan, dan pengungkapan atas dasar akuntansi agrikultur. Sumber data dalam penelitian ini berupa studi literatur dan penelitianpenelitian sebelumnya serta data sekunder berupa laporan keuangan yang telah dipublikasikan. Data studi literatur merujuk pada surat edaran ketua Bapepam No. SE-02/PM/2002, PSAK 32 tentang kehutanan dan PSAK 69 tentang agrikultur, dan data penyajian laporan keuangan perusahaan-perusahaan yang terdaftar di Bursa Efek Indonesia yang tergolong sektor agrikultur selama periode penelitian yakni tahun 2017 hingga tahun 2019 pada kuartal ke 3.

Metode analisis dalam penelitian ini dengan membandingkan laporan keuangan perusahaan dalam perlakuan akuntansi yang diatur secara rinci dalam PSAK 69 tentang akuntansi agrikultur, terutama terkait dengan penerapan fair value terhadap aset biologis sebelum dan sesudah diimplementasikan. Analisis kualitatif dilakukan untuk memberikan informasi penjelasan dampak dan penerapan PSAK 69 tentang akuntansi agrikultur pada perusahaan di industri agrikultur Indonesia.

\section{HASIL PENELITIAN DAN PEMBAHASAN}

Penelitian ini menganalisis penerapan PSAK 69 agrikultur dengan cara membandingkan sebelum dan setelah diterapkan PSAK 69agrikultur, yang berlaku secara efektif 1 Januari 2018. Secara garis besar PSAK 69 membahas tentang perlakuan aset biologis yang masih penuh pertimbangan dalam penerapannya. Analisis kualitatif komparatif akan menjelaskan perbedaan PSAK 32 Kehutanan, surat edaran ketua Bapepam SE-02/PM/2002 dengan PSAK 69 agrikultur ditunjukkan pada Tabel 1 yang dibedakan menurut ruang lingkup dan format pelaporan yang digunakan, deskripsi tentang aset biologis, pengakuan aset biologis, pengakuan aset selain aset biologis, pengakuan nilai wajar, hibah pemerintah, keuntungan/kerugian, laporan laba/rugi, dan laporan arus kas. 


\section{Tabel 1}

Perbandingan PSAK 69, SE Bapepam No. SE-02/PM/2002 dan PSAK 32

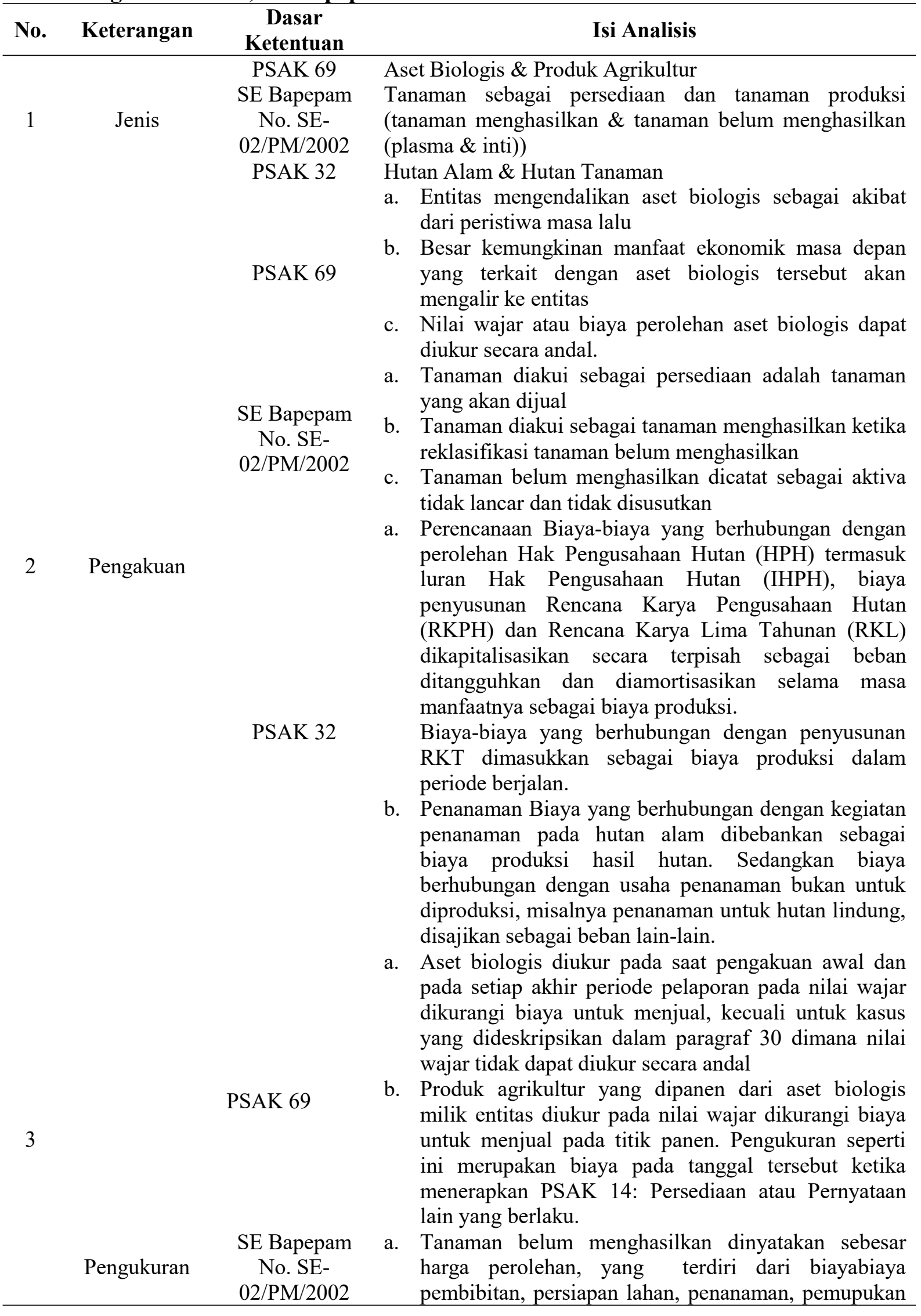


dan pemeliharaan, alokasi biaya tidak langsung berdasarkan luas hektar yang dikapitalisasi, termasuk pula kapitalisasi biaya pinjaman dan rugi selisih kurs yang timbul dari pinjaman yang digunakan untuk mendanai tanaman belum menghasilkan selama periode-periode tertentu

b. Tanaman belum menghasilkan dinyatakan sebesar harga perolehan, yang terdiri dari biayabiaya pembibitan, persiapan lahan, penanaman, pemupukan dan pemeliharaan, alokasi biaya tidak langsung berdasarkan luas hektar yang dikapitalisasi, termasuk pula kapitalisasi biaya pinjaman dan rugi selisih kurs yang timbul dari pinjaman yang digunakan untuk mendanai tanaman belum menghasilkan selama periode-periode tertentu.

Untuk hutan alam, perusahaan diberikan hak untuk mengelola hutan yang tanamannya siap ditebang. Perusahaan tidak melakukan proses transformasi tanaman sampai dengan pohon tersebut siap tebang. Konsekuensinya, nilai tanaman tidak dapat dihitung PSAK 32 karena diserahkan pengelolaannya oleh negara bersamaan dengan pemberian izin. Sebagai gantinya, negara mewajibkan entitas untuk membayar iuran wajib dan melakukan penanaman kembali hutan yang telah ditebang. Beban yang timbul - terkait dengan kegiatan penanam dan pemeliharaan kembali hutan serta pembayaran iurandiakui sebagai harga pokok produksi pada saat terjadinya.

Keuntungan atau kerugian yang timbul pada saat pengakuan awal aset biologis atau produk agrikultur pada PSAK 69 nilai wajar dikurangi biaya untuk menjual dan dari perubahan nilai wajar dikurangi biaya untuk menjual aset biologis dimasukkan dalam laba rugi pada periode dimana keuntungan atau kerugian tersebut terjadi.

SE Bapepam Selisih antara harga jual dan nilai buku aktiva yang dijual No. SE- harus diakui dan dicatat sebagai keuntungan atau kerugian

Keuntungan atau kerugian

$02 / \mathrm{PM} / 2002$

PSAK 32 yang ditangguhkan.

Pendapatan operasional meliputi pendapatan dari penjualan hasil hutan, baik berupa kayu olahan, hasil tebangan maupun hasil hutan lainnya. Pendapatan harus diakui dengan menggunakan dasar akrual. Beban harus diakui dengan menggunakan dasar akrual. Harga pokok produksi kayu tebangan dan hasil hutan lainnya meliputi beban yang terjadi dalam hubungannya dengan kegiatankegiatan.

Merujuk pada PSAK 48: penurunan nilai aset dalam

PSAK 69 menentukan biaya perolehan, akumulasi penyusutan, dan akumulasi kerugian penurunan nilai.

SE Bapepam Penyusutan pada tanaman menghasilkan tergantung pada No. SE- jenis tanaman, umumnya menggunakan garis lurus; 02/PM/2002 sedangkan tanaman belum menghasilkan tidak disusutkan. Pada Hutan Tanaman Industri, biaya bunga pinjaman yang terjadi dikapitalisasi selama masa satu daur sebagai "HTI

PSAK 32 dalam pengembangan" dan diamortisasi selama masa konsesi sebagai biaya produksi. Amortisasi dimulai sejak penebangan dilakukan serta dibukukan sebagai biaya 
6 Pengungkapan

PSAK 69

SE Bapepam

No. SE-

$02 / \mathrm{PM} / 2002$ produksi. Amortisasi dapat dilakukan dengan menggunakan metode garis lurus atau metode Unit of Production.

1. Entitas mengungkapkan keuntungan atau kerugian gabungan yang timbul selama periode berjalan pada saat pengakuan awal aset biologis dan produk agrikultur, dan dari perubahan nilai wajar dikurangi biaya untuk menjual aset biologis.

2. Entitas mendeskripsikan setiap kelompok aset biologis (pengungkapan yang disyaratkan dapat berbentuk deskripsi naratif atau kuantitatif).

3. Entitas mengungkapkan:

a). keberadaan dan jumlah tercatat aset biologis yang kepemilikannya dibatasi, dan jumlah tercatat aset biologis yang dijaminkan untuk liabilitas

b). jumlah komitmen untuk pengembangan atau akuisisi aset biologis; dan

c). strategi manajemen risiko keuangan yang terkait dengan aktivitas agrikultur.

4. Entitas menyajikan rekonsiliasi perubahan jumlah tercatat aset biologis antara awal dan akhir periode berjalan; Jika tidak diungkapkan di bagian manapun dalam informasi yang dipublikasikan bersama dengan laporan keuangan, maka entitas mendeskripsikan:

a). sifat aktivitasnya yang melibatkan setiap kelompok aset biologis; dan

b). ukuran atau estimasi nonkeuangan dari kuantitas fisik: setiap kelompok aset biologis milik entitas pada akhir periode; dan keluaran produk agrikultur selama periode tersebut

a). Untuk tanaman telah menghasilkan:

1. Rincian nilai tercatat dan akumulasi penyusutan menurut jenis tanaman

2. Rekonsiliasi nilai tercatat awal tahun dan akhir tahun tanaman untuk setiap kelompok selama paling tidak 2 tahun terakhir.

3. Status tanah yang digunakan untuk menanam.

4. Nilai tanaman telah menghasilkan berdasarkan area/lokasi penanaman

5. Perbandingan saldo tanaman belum menghasilkan selama paling tidak 2 tahun.

6. Tanaman yang dijaminkan.

b). Untuk tanaman belum menghasilkan

1. Mutasi tanaman belum menghasilkan sebagai berikut : (Saldo awal; Tambahan tahun berjalan (biaya langsung \& jumlah kapitalisasi biaya pinjaman, dan rugi kurs dalam hal terjadi depresiasi luar biasa); Pengurangan tahun berjalan (jumlah yang direklasifikasi ke tanaman telah menghasilkan \& pengurangan lainnya); Saldo akhir)

2. Nilai tanaman dalam Perkebunan Inti Rakyat / Perkebunan Inti Plasma yang menjadi milik perusahaan (inti) dan tanaman yang bukan milik perusahaan (perkebunan rakyat/perkebunan 
PSAK 32

plasma).

3. Cadangan kerugian yang mungkin timbul pada plasma.

1. Realisasi kegiatan dan biaya yang berhubungan dengan pelaksanaan penanaman kembali hutan alam

2. Untuk HTI, diungkapkan realisasi luas tanaman pada periode berjalan dan akumulasinya

3. Apabila tidak tersedia pohon siap tebang, maka biaya yang berhubungan dengan usaha pemeliharaan dan pembinaan hutan dikapitalisasi sebagai "HTI dalam pengembangan" sampai umur siap tebang dan diamortisasi selama jangka waktu masa konsesi, dan amortisasi dimulai sejak penebangan dilakukan serta dibukukan sebagai biaya produksi;

4. Apabila tersedia pohon siap tebang, biaya yang berhubungan dengan usaha pemeliharaan dan pembinaan hutan tersebut dibukukan sebagai biaya produksi

5. Biaya yang berhubungan dengan penyusunan AMDAL, RPL dan RKL dikapitalisasi sebagai beban yang ditangguhkan dan diamortisasi selama masa manfaatnya sebagai biaya produksi.

6. Beban penghentian produksi yang disebabkan kejadian normal dan rutin seperti yang disebabkan karena keadaan cuaca/musim, dibukukan sebagai biaya produksi. Beban penghentian produksi lainnya, seperti yang disebabkan oleh bencana alam/kebakaran, disajikan sebagai pos luar biasa.

Sumber: Data Sekunder yang Diolah, 2019

\section{Tabel 2}

Analisis Perbandingan Sebelum dan Setelah Penerapan PSAK 69 Tentang Akuntansi Agrikultur pada Perusahaan di Industri Agrikultur

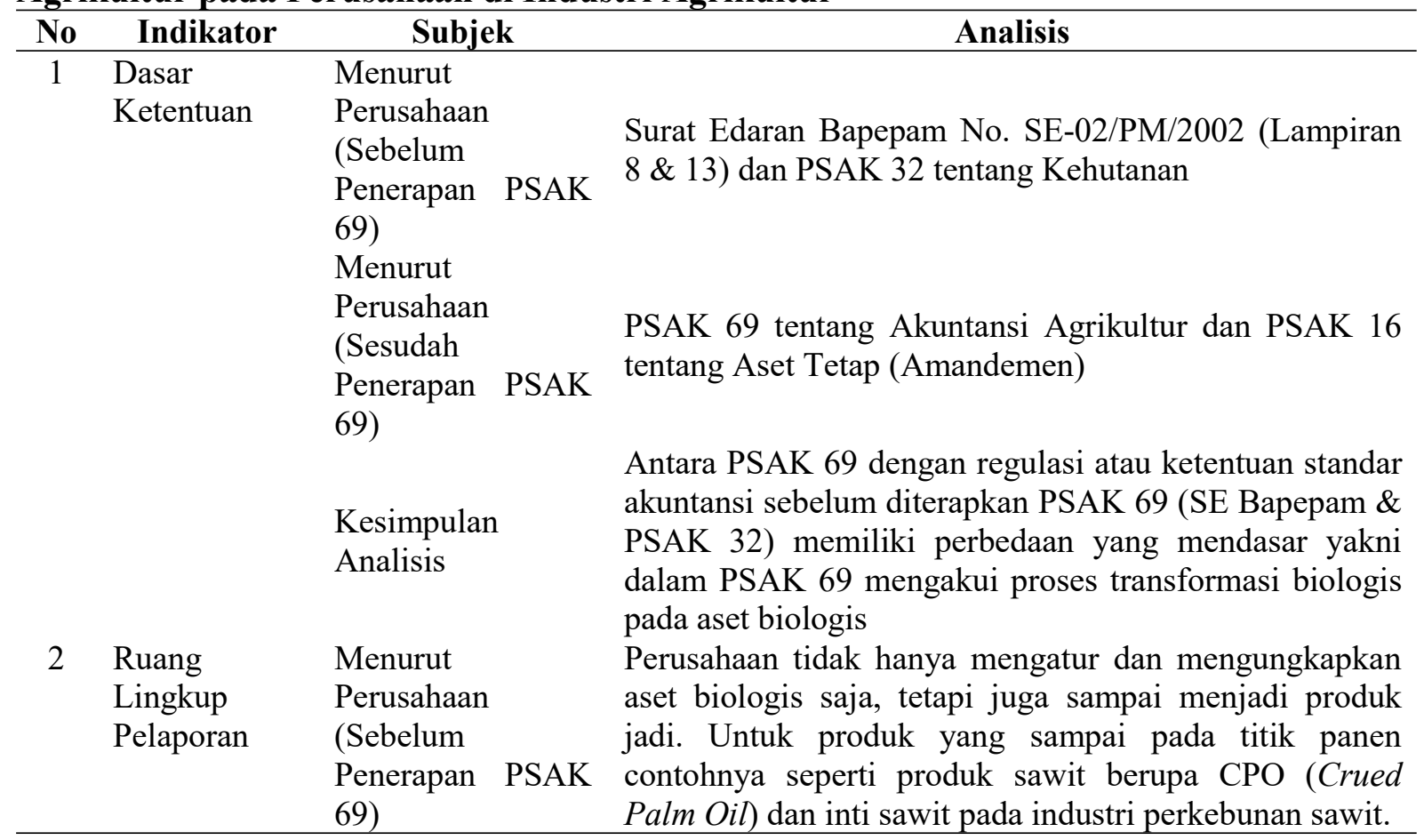




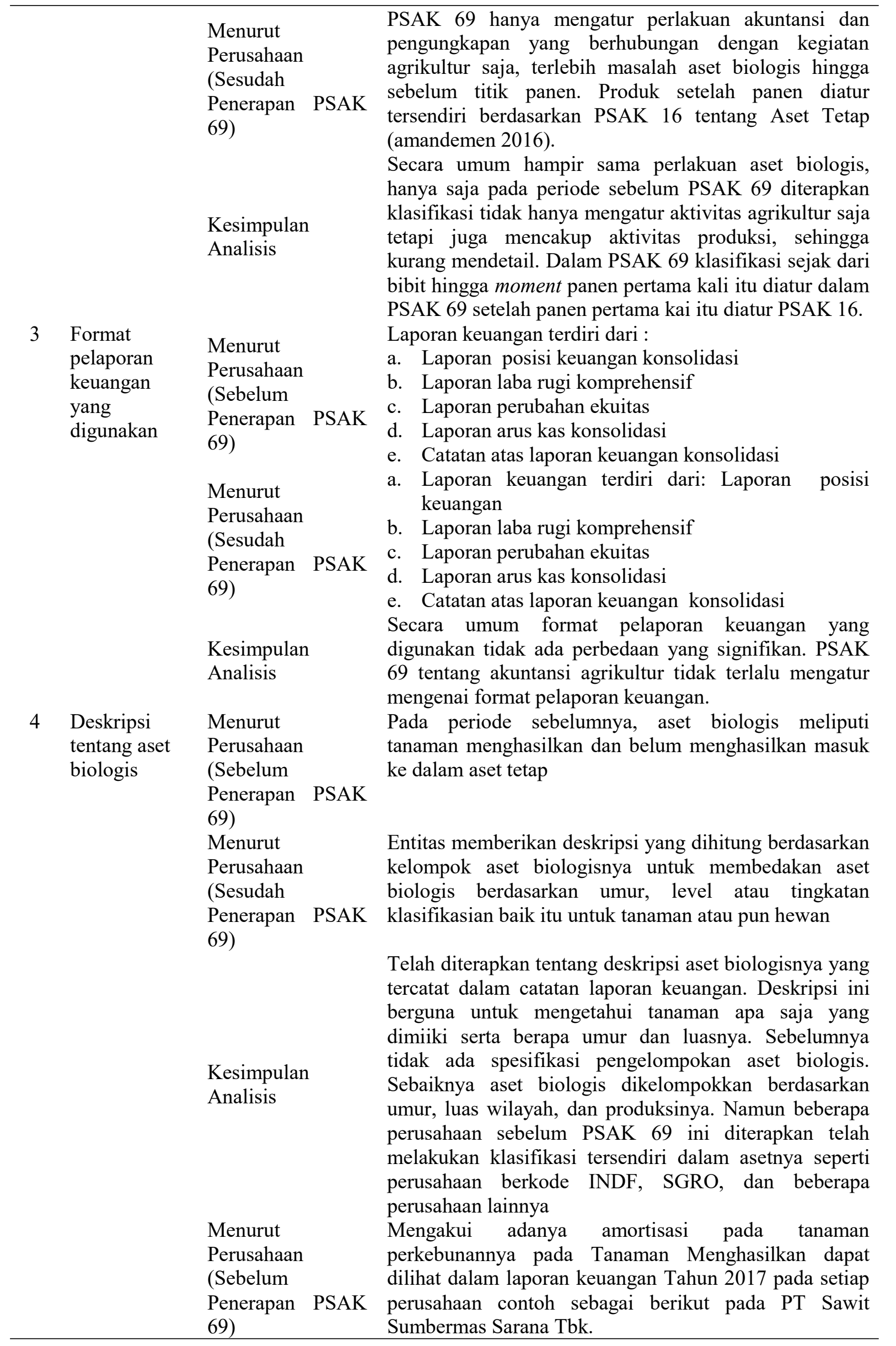




Menurut
Perusahaan
(Sesudah
Penerapan PSAK
69)

Kesimpulan Analisis

6 Pengakuan aset selain aset biologis

Menurut Perusahaan

(Sebelum Penerapan 69)

Menurut Perusahaan (Sesudah Penerapan PSAK 69)

Kesimpulan Analisis

7 Pengakuan nilai wajar
Pengakuan Tanaman Menghasilkan (TM) dan Belum Menghasilkan (TBM) tidak terdapat akumulasi amortisasi, melainkan dibebankan ke akun beban pokok penjualan atas Tanaman Produktif (Bearer Plants). Contoh penyajiannya dapat dilihat sebagai berikut PT Sawit Sumbermas Sarana Tbk Tahun 2018.

Pengukuran aset biologis tidak mengakui adanya amortisasi, namun pada tanaman produktif (tanaman menghasilkan dan tanaman belum menghasilkan) pada PSAK 69 mengakui adanya akumulasi depresiasi pada tanaman diatur dalam PSAK 16 (amandemen) tentang aset tetap. Pada periode sebelumnya masih mengakui adanya akumulasi depresiasi pada aset biologis. Dapat dilihat pada catatan atas laporan keuangan.

Aset tetap yang dicatat pada periode sebelum penerapan PSAK 69 oleh perusahaan adalah bangunan, prasarana mesin, peralatan kantor, kendaraan dan alat berat yang digunakan di perusahaan.

Tanah yang terkait dengan aktivitas agrikultur tentang properti, pabrik, dan peralatan atau terhadap aset tidak berwujud yang berhubungan dengan akuntansi agrikultur tidak diatur dalam PSAK 69

Terdapat perbedaan dalam pengakuan aset tetap selain pengakuan aset biologis, yaitu pengakuan berdasarkan sebelum penerapan dan setelah PSAK 69. Tetapi dalam catatan perusahaan dijelaskan bahwa perusahaan akan menggunakan PSAK 16 amandemen untuk mengatur aset tetapnya yang tidak mengatur lagi mengenai properti dan investasi.

Nilai wajar berasal dari harga pasar (harga spot/ harga yang pada saat itu sedang berlaku), model arus kas diskonto dan model penentuan harga opsi yang sewajarnya. Jika nilai wajar tidak dapat diukur secara andal maka pengukuran yang digunakan yaitu: aset tidak lancar lainnya dikurangi simpanan yang dapat dikembalikan dan dicatat pada biaya perolehan.

Menurut

Perusahaan

(Sebelum

Penerapan PSAK 69)

\footnotetext{
Menurut

Perusahaan

(Sesudah

Penerapan PSAK 69)
}

Jika tidak diperdagangkan di pasar aktif, nilai wajar ditentukan dengan menggunakan teknik penilaian yang meliputi penggunaan transaksi pasar terkini yang dilakukan secara wajar (arm's-length market transactions) dikurangi dengan biaya-biaya.

Biaya penjualan yang dicatat perusahaan adalah sebesar biaya perolehannya yaitu semua biayabiaya yang dikeluarkan sampai tanaman tersebut dapat menghasilkan ditambah range laba yang diinginkan.

1. Cara menentukan nilai wajar (PSAK 69): Aset biologis diukur pada saat pengakuan awal dan pada setiap akhir periode pelaporan pada nilai wajar dikurangi biaya untuk menjual, kecuali untuk kasus yang dideskripsikan dalam paragraf 30 dimana nilai wajar tidak dapat diukur secara andal.

2. Produk agrikultur yang dipanen dari aset biologis 
milik entitas diukur dengan nilai wajar pada titik panen hal ini dapat dilakukan saat PSAK 14 diterapkan.

3. Pengukuran nilai wajar aset biologis atau produk agrikultur dapat didukung dengan mengelompokkan aset biologis atau produk agrikultur sesuai dengan atribut yang signifi kan

Jika nilai wajar tidak dapat diukur secara andal, maka aset biologis harus diukur berdasarkan biaya dikurangi akumulasi penyusutan dan akumulasi kerugian penyusunan nilai. Setelah nilai wajar aset biologis dapat diukur secara andal, entitas harus mengukurnya pada nilai wajar dikurangi estimasi biaya penjualan (PSAK 69).

Dalam pengakuan nilai wajar yang digunakan, semua perusahaan telah menerapkan nilai wajar berdasarkan PSAK 69 yaitu menggunakan harga yang berlaku saat

Kesimpulan Analisis

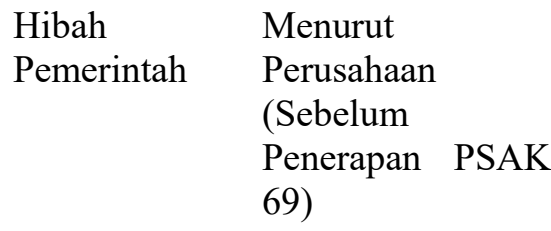

Menurut Perusahaan (Sesudah Penerapan PSAK 69)

Kesimpulan Analisis

9 Keuntungan/ Menurut kerugian Perusahaan (Sebelum Penerapan PSAK 69)

Menurut Perusahaan (Sesudah Penerapan PSAK itu (harga spot). Hal ini dijelaskan dalam catatan atas laporan keuangan.

Jika nilai wajar tidak dapat diukur secara andal, maka nilai wajar diukur berdasarkan biaya dikurangi akumulasi penyusutan dan akumulasi penurunan nilai/nilai wajar dikurangi estimasi biaya penjualannya Dalam SE Bapepam No. SE-02/PM/2002 Lampiran 13 tidak mengatur hibah pemerintah yang diterapkan perusahaan

Hibah pemerintah tanpa syarat yang berkaitan dengan aset biologis diukur pada nilai wajar dikurangi dengan estimasi biaya penjualan dan harus diakui sebagai pendapatan pada saat, dan hanya jika hibah pemerintah menjadi piutang (PSAK 69). Jika hibah pemerintah memiliki sifat bersyarat, termasuk di mana hibah pemerintah mensyaratkan entitas untuk tidak terlibat dalam kegiatan agrikultur tertentu, suatu entitas harus mengakui hibah pemerintah sebagai pendapatan (PSAK 69)

Pada laporan keuangan sebelum penerapan PSAK 69 tidak mengatur secara jelas pengungkapan hibah pemerintah, namun pada PSAK 69 diterapkan pengungkapan tentang hibah pemerintah dijelaskan pada paragraf 34-38 dan sangat berhubungan dengan PSAK 61 tentang hibah pemerintah

Pada keuntungan dan kerugian akibat pengakuan aset ini dimasukkan ke dalam laporan laba/rugi, tidak hanya pada pengakuan aset biologisnya tanaman produktif saja.

Keuntungan atau kerugian yang timbul pada saat pengakuan awal aset biologis pada nilai wajar dikurangi biaya untuk menjual dan dari perubahan nilai wajar dikurangi biaya untuk menjual aset biologis dimasukkan 


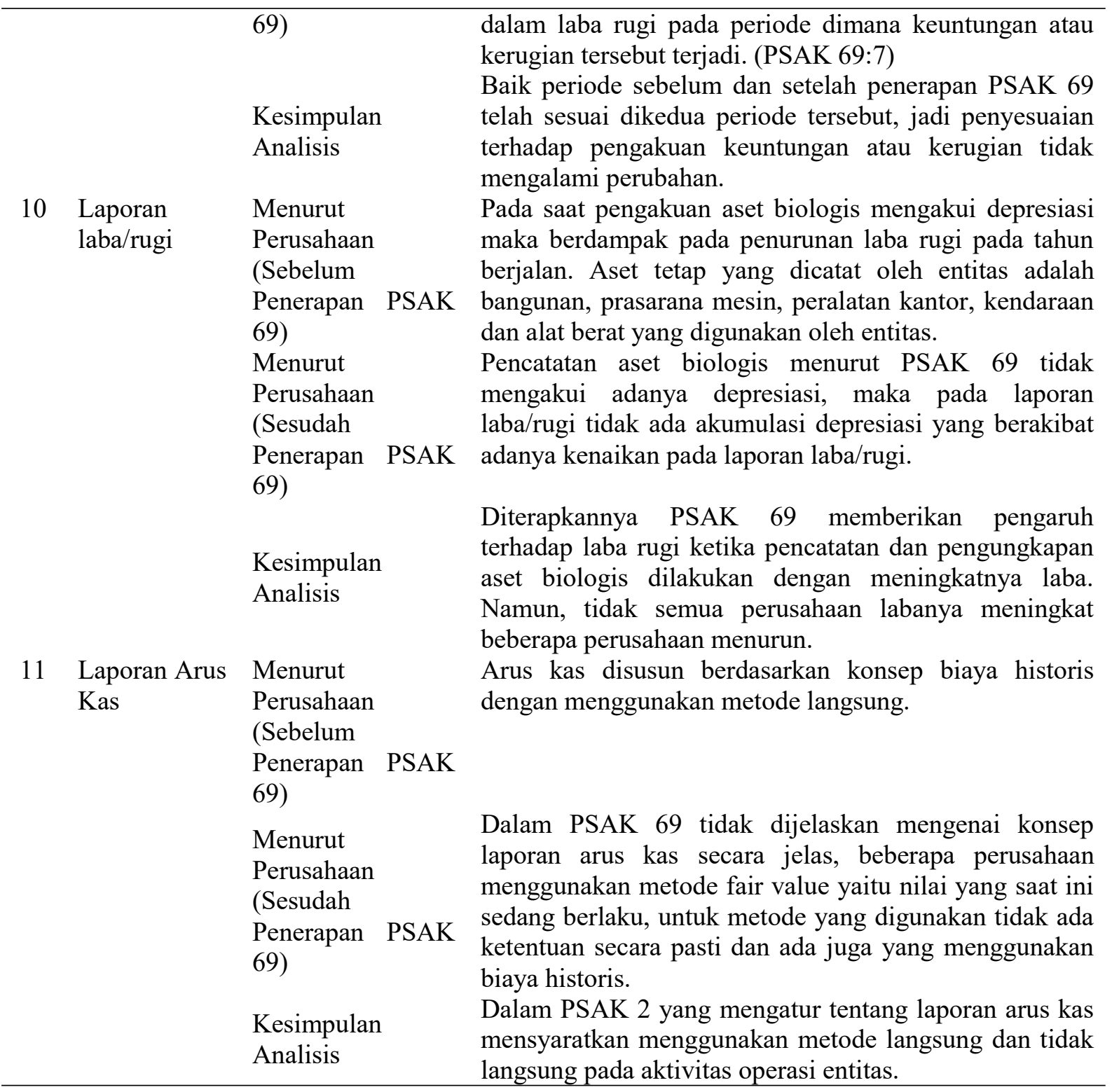

Sumber: Data Analisis yang Diolah, 2019

\section{SIMPULAN}

Sektor agrikultur merupakan sektor yang tidak dapat anggap sepele dalam mendukung perekonomian Indonesia. Penerapan PSAK 69 tentang agrikultur merupakan bentuk upaya mendorong kemajuan sektor agrikultur untuk menyajikan laporan keuangan yang lebih jelas, tertata, pencatatan secara accrual, pengakuan aset dinilai berdasarkan nilai wajar dan bersifat informatif terhadap perkembangan nilai atas proses transformasi biologis pada aset biologis dan produk agrikultur terdokumentasi dengan jelas. Pengklasifikasian aset menjadi hal yang mendasar pada PSAK 69 tentang agrikultur ini, sejak dari bibit hingga saat dipanen (harvest) semua didokumentasikan dengan secara baik. Sehingga perusahaan sektor agrikultur dalam penerapan PSAK 69 tentang agrikultur, pengungkapan atas laporan keuangannya dapat dinilai secara adequate disclosure (pengungkapan yang memadai), fair disclosure (pengungkapan 
wajar) dan full disclosure (pengungkapan penuh) (Soewardjono, 2010).

\section{REFERENSI}

Badan Pengawas Pasar Modal dan Lembag Keuangan. (2002). Surat Edaran Bapepam No. SE-02/PM/2002 Pedoman Penyajian dan Pengungkapan Laporan Keuangan Emiten atau Perusahaan Publik. Jakarta: Badan Pengawas Pasar Modal dan Lembag Keuangan.

Badan Pusat Statistik. (2018). Data Statistik Sektor Pertanian. Jakarta: Badan Pusat Statistik

Brigham, E. F., \& Houston, J. F. (2014). Dasar-dasar Manajemen Keuangan. Jakarta: Salemba Empat.

Dusa, A. \& Thiem, A. (2019). Qualitative Comparative Analysis with R; A User's Guide. New York Heidelberg Dordrecht London: Springer.

Ikatan Akuntan Indonesia. (1994). Pernyataan Standar Akuntansi Keuangan 32 Tentang Kehutanan. Jakarta: Dewan Standar Akuntansi Keuangan.

Ikatan Akuntan Indonesia. (2016). Pernyataan Standar Akuntansi Keuangan 69 Tentang Agrikultur. Jakarta: Dewan Standar Akuntansi Keuangan Kehutanan PSAK 32. Economic Business \& Accounting Review Volume III No. 12010.

Martani, D. (2010). Dampak Pencabutan PSAK: Akuntansi.

Martani, D. (2018). Pemahaman Akuntansi Agrikultur PSAK No.69, Workshop Pendidikan Profesi Lanjutan Akuntansi. Bandarlampung. 1-2 November 2018.

Scott, W. R. (2015). Financial Accounting Theory 7th Edition. Canada: Pearson.

Soewardjono. (2010). Teori Akuntansi: Pengungkapan dan Sarana Interpretatif. Edisi ke-3. Yogyakarta: BPFE. 